\title{
Women Candidates, social media, and The Politicization of Religious Identity and Women Islamic Organizations in Indonesia's 2019 Election
}

\author{
Muhammad Mahsun, Tholkhatul Khoir, Solkhah Mufrikhah, \\ Tika Ifrida Takayasa, Masrohatun \\ Lecturers at Faculty of Social and Political Science, \\ Universitas Islam Negeri Walisongo, Semarang, Indonesia
}

\begin{abstract}
In the recent decade, most of the Indonesian politicians in Indonesia have become acquainted with the Internet and social media usage especially during campaigns in an election. Concerning this trend, some analyses have investigated the proliferation of social media used by presidential and vicepresidential candidates or the local head candidates in election. However, little attention has been directly to explore how women candidates of parliamentarian use social media as political strategies to mobilize electoral supports in the emerging democracy of Indonesia. By using qualitative method and the concept of political identity, this paper explores how women candidates using social media platform such as Facebook and Instagram by politicizing religious symbols and women organization-Islamic base in constructing piety in Islam to mobilize electoral supports in Indonesia's 2019 legislative election. We argue that using social media platform to politicize religious identity supported by the large women organization-Islamic base can give a strategic advantage for women candidates in Indonesian electoral politics.
\end{abstract}

Keywords: Women Candidate; Piety; Religious Identity; Women OrganizationIslamic Base; Legislative Election; Indonesia

\section{Introduction}

The internet and social media has been increasingly playing a vital role in electoral campaigns in contemporary Indonesian democracy. As the biggest Muslim democracy country in the world, Indonesia has 268 million populations, and based on the report of ISEAS Singapore that in 2019 there are 150 million of them are active internet and social media users with mostly identified as eligible voters (ISEAS 2019). Many scholars therefore give serious attention to explore usage of social media like Facebook, Twitter, Instagram, Youtube, and lately Vlog (video blog) - that recently gains popularity among digital citizens as a new media to express thoughts and experiences - as platforms that provide a widened range of strategic choices for political campaigns in Indonesian electoral politics, especially in 2014 and 2019 election. Concerning this trend, some analyses have investigated the proliferation of social media used by presidential and vice-presidential candidates or local head candidates in 
mobilizing electoral supports (Abdillah 2014; Johansson 2016; Budiharto dan Meiliana 2018; Irawanto 2018). Otherwise, little attention has been directly to explore how women candidates of parliamentarian usage social media as political strategies to mobilize electoral supports in the emerging democracy of Indonesia. This fact prompts an urgent need for the study of digital politics in new media world, especially on how women candidate usages social media as a strategic advantage to support their other strategies that used beyond social media to win Indonesia's 2019 election; and to what extent the women candidates address the topics or issues most important to a mass audience through social media.

To fill the gap, this article reveals how women candidate campaigning through social media, especially in Facebook and Instagram Platform, by politicizing religious symbols and women organizations to construct piety in Islam to win the 2019 Indonesian election. Using qualitative method and the theories of identity politics and social capital, this article focuses on exploring some women candidates from Muslimat-Fatayat NU win the seats of the provincial parliament of Central Java in the 2019 Indonesian legislative election. We argue that using religious symbols to construct piety and it is strengthened by posting some photos of Islamic women organization in social media platforms give a strategic advantage for women candidates in Indonesian electoral politics to win the provincial parliamentary seats.

\section{Results and Discussion}

\subsection{Theoretical Perspective: Identity Politics and Social Capital}

The concept of identity politics was first put by L.A. Kauffman and became popular in the 1970s. At the beginning of its development, it emphasized several things such as race, ethnicity, feminism, and marginalized social groups. Meanwhile, in journey, the discussion of identity politics has penetrated into issues of religion, culture and belief (Maarif, 2012). Identity politics itself is defined as a political concept and movement whose root of concern is difference as a major political category, Agnes Haller (1995) in (Lestari, 2018). If Agnes emphasizes differences, Donald L Morowitz can be said to be a little more assertive because he defined identity politics as providing a clear line to determine who will be included and who will be rejected (Haboddin, 2012).

The phenomenon of identity politics in the context of Indonesian can be derived from various things. This is becaused Indonesia consists of various tribes, ethnicities, cultures, religions etc. In this study, the identity politics that will be examined is how the legislative candidates for the Central Java DPRD whose backround from Fatayat of NU in the Central Java region can win political contestations by using their Fatayat identity to increase electability. In addition, the fatayat identity that is owned can also be used as social capital. Fatayat can be regarded as social capital because it is part of one of the organization structural of NU, where Nahdlatul Ulama is one of the largest religious organizations in Indonesia with more than 90 million followers. Many people choose NU as a religious forum, so this is a social power that can be used for many things, including providing political support.

The number of NU members spread across various regions in Indonesia is indeed a sufficient capital in strengthening electability. Social capital itself according to Burt (Yangmin Kim* and Albert A. Cannella, 2008) is as relationships with others - friends, colleagues, and more general contacts through whom you receive opportunities to use your financial and human capital". And in the same article, Putnam also argues that social capital, as a property of groups or communities (or even nations), rather than individuals, and defined it as "features 
of social organization, such as trust, norms, and networks that can improve the efficiency of society by facilitating coordinating actions.

\subsection{The Proliferation of social media and Identity Politics in Indonesia}

Indonesian society has become an information society that is supported by the use of internet media in everyday life. Data survey conducted that Indonesia's internet penetration at the end of March 2021 was 76.8 percent of the total population. According to Internetworldstats data, internet users in Indonesia reached 212.35 million with an estimated total population of 276.3 million. With this achievement, Indonesia is ranked $4^{\text {th }}$ among countries of the world (internetworldstats, 2021). With this high use of the internet, social media for millennials becomes primary needs in Indonesia. Social media is the network used to communicate in text form, videos, blogs, photos and status updates on Facebook, Instagram and others. The young women's candidates realized the importance of the use of social media in the electoral political contestation in the digital era. Social media is also used as a campaign medium to attract voters, including the millennial generation. High use of social media in society has the opportunity to become a means for political actors to gain public votes in addition, it is also supported by the condition of Indonesia as a democratic country that provides space for community to express their aspirations. In this context, social media can also be a means of forming public opinions.

However, the existence of social media in the political field is also exposed to actions or exploitation of identity politics. This practice of identity politics usually rife happens during the election was held. Even though the election had been ended, but political exploitation identity still exists, including residual from before. This condition of course will give birth to social public disintegration. Based on the results of a survey in 2018 conducted by the Indo Institute Survey and Strategy (ISS) on issues identity politics. On the regional election 2018, the data obtained that $59-71 \%$. Respondent tend not to choose candidate with different religion or faith. $60-69 \%$ based on issues or sentiments of race or ethnicity. In addition, respondents also still choose based on descendants or primordial 51-62\%. respondents (Indo Institute Survey and Strategy (ISS), 2018)

Political identity is a political mechanism for organizing identity (both political identity and social identity) as a source and means of politics. The study of identity politics includes two recognized categories of identity, namely social identity and religious identity as the subject (Haboddin, 2012). Identity politics, including through social media, is often defined as politics that puts forward emotional relations and undermines rational considerations it's called emotive politics. This matter has become more massive since the widespread use of social media coupled with the behavior of the millennial generation who tend to be less aggressive in terms of politics, so that the choices made in the election are more because they are encouragement and do not prioritize choices because they are based on considerations of public benefit. The choice is made based on identity, because of racial, ethnic, primordial relations, and also because of the similarity of religious beliefs.

The problem with the division of identity politics in Indonesia today is inseparable of political interests driven by political elites to gain to maintain power by manipulating identity politics in Indonesia. This election process is the main point of the development of divisions between the spirit of nationalism and religion in Indonesia. Unsuccess government in carrying out and wise government coupled with greed to maintain power makes politics identity as the most powerful vehicle to get the people's voice. In this case women candidate's use the social 
media and political identity to gain more votes and sympathy as piety women politicians in Islam (Lestari, 2018).

The practice of identity politics carried out by women candidates on his social media account reflect new concepts in practice identity politics. Identity politics practice does not only take place in space offline, but also takes place in online context. The use of Identity politics on social media by women candidates are getting stronger because supported by a number of religious communities called Fatayat an Muslimat NU as a biggest religious organization in Indonesia.In social media, ongoing cyberwar carry messages of identity politics. Everyone makes it possible to carry out identity politics through uploads, tweets, and captions to support tendencies including political candidate to gain more votes in legislative elections (Triantoro, 2019)

\subsection{Politicising Religious Identity and Women Islamic Organizations in social media}

In the 2019 Indonesia legislative elections at local level, there were some women candidates who have background as a leader or elites in the structure of Muslimat-Fatayat NU and from the National Awakening Party (PKB) and the United Development Party (PPP) two political parties in Indonesia that have strong affiliations with NU - won the parliament seats in the Central java. Based on our research found that the winning of NU's women candidates in gaining parliamentary seats of Central Java Province in the 2019 elections as explained above were predominantly not only influenced by a network of NU women's organizations they have, but also determined by their strategic campaign in social media platforms such as Facebook and Instagram to expand electoral support. Based on our interviews with women candidates in the 2019 election campaign period, in general, they realized the importance of the use of social media in the electoral political contestation in the digital era. Many candidates believe that campaigning in social media has a positive impact on producing their popularity and potentially winning the parliamentary seats in Indonesia's 2019 legislative elections, although it is difficult to measure their effectiveness. That can be seen from a large number of internet citizens (netizens) who give a "like", comment, and share the statuses that the candidates are made on their social media platform (interviews, female candidates, March-May 2019).

Social media for women politicians, especially young people (under 45 years), becomes an important instrument for campaigning in virtual space to influence the preferences of voters who actively use the internet. Through social media, candidates can campaign for themselves across space and time, as well as needs low energy. Besides, several women candidates elected in the 2019 election also acknowledged that the existence of social media makes it easy for them to communicate and coordinate with the success team and supporters. Social media also provides a large space for candidates to share all their campaign activities in a virtual space so that it can be known and consumed by the public to get political support to win parliamentary seats in Central Java Province.

This is also experienced by many other candidates who campaign through social media in democratic countries around the world. Related to this, Daoust and Sullivan (2017) explain that the internet in democratic countries gives a positive effect on information as it offers many opportunities for political participation and political engagement, provides access to information, reduces participation cost, and offers an interactive space for citizen and political leaders alike. Furthermore, social media platform, such as Facebook and Instagram, has the potential of providing a public sphere for political debate and influences voter preference in the election. 
The results of our analysis on the number of Facebook and Instagram accounts owned by women candidates, there are several strategies used as political campaigning on social media platforms during the 2019 election campaign period in Central Java. First, social media is used by candidates to construct themselves as figures of piety women politicians in Islam. Selfconstruction as a piety figure is done by making many statuses or uploading photos that contain spiritual splash or religious speech; invite the public (netizens) to do politics with well behaved; and information to the public that the candidate is run in politics for Ummah by prioritizing political ways that are rahmatan lil'alamin. Also, the construction of figures as piety women politicians was carried out by uploading religious speech activities carried out by NU female candidates in the Muslimat and Fatayat communities on social media platforms such as Facebook and Instagram. And at the same time, the candidates give an explanation in their status on social media about the invitation to vote them in the 2019 elections.
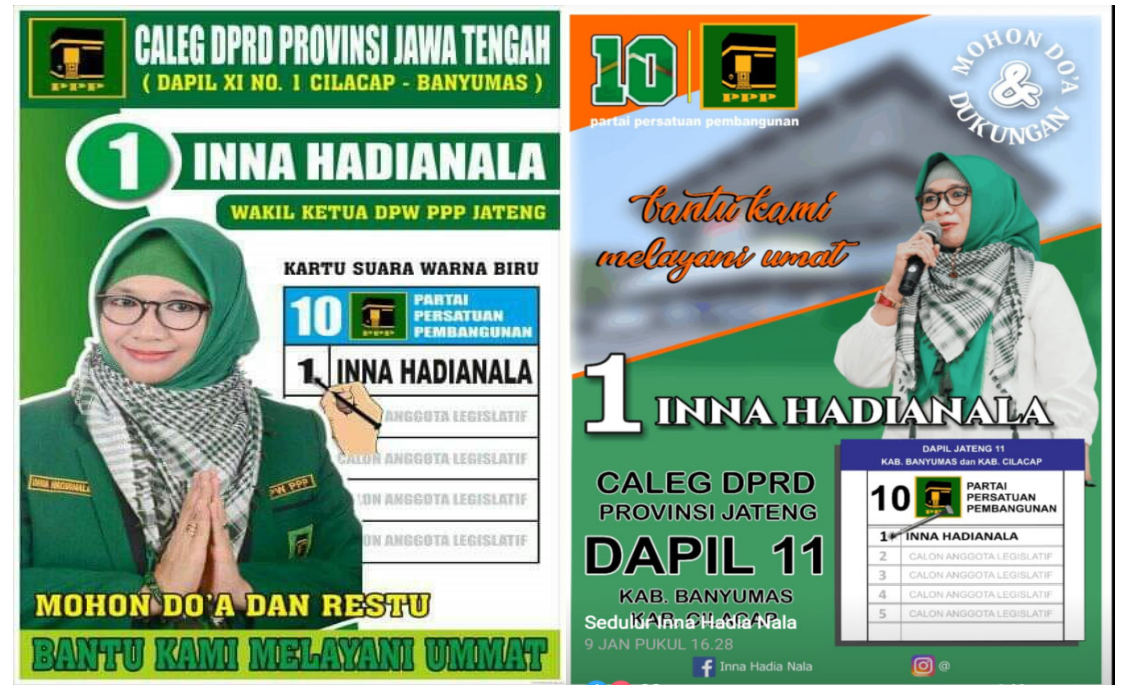

Fig. 1. Photos of Candidate Campaigns to building piety in Islam in Social Media

Second, candidates often upload photos and videos of their political campaigns in the women's community of Muslimat and Fatayat NU or majelis taklim (religious learning forum) on social media platform such as Facebook and Instagram owned by candidates, and on social media platform specifically created by successful teams or candidates to campaign in virtual space. This kind of political campaign strategy is used by candidates as a way to show the public that their candidacy in the 2019 elections has great support from the community of women voters who have affiliations with the largest women's organizations in Indonesia, namely Muslimat and Fatayat NU. This is an important social capital that they are trying to solidify into virtual space to hegemony voters who have NU religious affiliation to provide sympathy and political support for winning in election. In addition, the strategy of campaigning for women candidates on social media was carried out as a way to strengthen their political identity and religious ideology that they were part of the elite and citizens of NU who put forward the views of moderate Islam. This confirmation of identity is carried out to attract political sentiment and support from communities that share the same ideology, identity and religious views. 


\section{\#fatayatNu \\ \#muslimatNu \\ \#Alhikmahponpes}

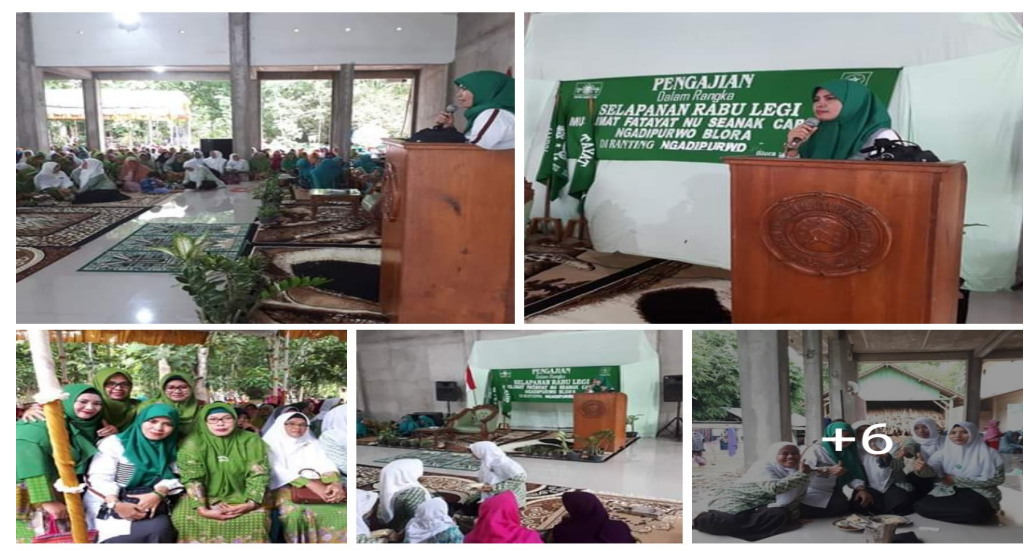

Fig. 2. Photos of Candidate Campaigns in Fatayat Community uploaded in Social Media

This kind of political strategy provides electoral advantages for candidates to take position on the condition of polarizing election that divide society in conservative, moderate and secular nationalist groups. This condition has strengthened since political campaign in 2014 Presidential Election and 2017 Jakarta Gubernatorial Election. Nastiti and Ratri said that Islamist organizations as Muslimat and Fatayat NU matter because they have organizational capacity and political patronage which are successful in penetrating society. They have organizational capacity at the grassroots level, derived from decades of social outreach in "non-political" settings during the New Order era (1966-98) (Nastiti dan Ratri 2018).

The political influence of Islamic organizations shape individuals is a piety political subject. This piety aspect is defined the right and wrongs of political choices (Nastiti dan Ratri 2018).This political strategy called 'emotive politic' or the political preference which only based on emotional ties. The candidates are capitalizing Fatayat networks in the virtual realm to mobilize votes using social media. They build narratives of these political identities religious image and Islamic moderation which counter the radicalism. These are important to maintain public sentiment and popularity as piety or religious practices in the society. These emotive appeals are technically effective on creating a shared feeling that unites all classes and groups in urban or rural society. This emotional experience and expression facilitated by major group of Islamic organization as a mode of political mobilization (Nastiti dan Ratri 2018).

From the explanation above, we argue that the issues of religious piety and moderation of Islam were widely used as political commodities and issues by NU women candidates for electoral support mobilization in social media platforms. And from our investigation, what was done by NU female candidates in Central Java was also mostly done by the most of Islamic women candidates in the 2019 Indonesian elections. The practice of campaigns like this coincided with the increasingly widespread movement of Hijrah in Islam carried out by many middle-class communities living in the city area. 


\section{Conclusion}

The study of the winning candidates, who have the background of NU, in contesting to gain parliamentary seats in Central Java Province explored in this article provides a different perspective in the study of women and politics in Indonesian politics in the social media era. The case of the winning candidates in Central Java who used the social media platforms such as Facebook and Instagram and supported by women Islamic organization to construct political identity and themselves as a Pious and moderate figure in Indonesia's 2019 election deserves to be appreciated.

The experience of women candidates in Central Java is an important lesson, that women candidates who want to be elected in election for public office mush not be from political dynasties and have strong support from local political elites or rely on money politics in the form of vote-buying as mostly done by male candidates in newly democratic countries. In the context of contemporary Indonesian politics, women in many regions who have a good strategy to use issues and build identity politics, take public emotion of women voters through social media platforms, have the same chance to win in elections. With the presence of social media, a woman candidate can target more of the women's community as the largest voter in Indonesia across broad geographical barriers. For authors, this condition can be the chance to encourage increased representation of women in the Indonesian parliament at the local and national level.

The question is can women be a politician and candidate to win the election contestation in Indonesia? This study shows that in the context of electoral politics dominated by patriarchal systems, women and the existence of social media can be important assets that have incentives to support women candidates to win in elections. This opportunity can be obtained when women have a large network of women's organizations that are important social capital that can support their election campaigns. The opportunity for women candidates in winning elections will be greater when the female candidate can also capitalize some issues and their women organization in a virtual space through social media platforms such as Facebook or Instagram to get more political support from voters who have the same identity. The same experience has also been experienced by some female candidates in the United States (Herrnson, Lay, \& Stokes 2003:251).

Contestation in the election is a manifestation of war carried out by peaceful means. In an open proportional electoral system, every male and female candidate is forced to compete with fellow candidates both outside the party and intra-party. Therefore, women candidates must be able to design good strategies to obtain electoral support from a large number of voters, including constructing themselves as part of the political identity of the larger community groups in the context of politically polarized Indonesian society.

\section{References}

[1] Abdillah, Leon A. 2014. "Indonesian's Presidential Social Media Campaigns." In Seminar Nasional Sistem Informasi Indonesia, , Indonesian's Presidential Social Media Campaigns.

[2] Affiah, Neng D. et al. 2005. Menapak Jejak Fatayat NU: Sejarah gerakan, pengalaman dan pemikiran, Jakarta: Pucuk Pimpinen Fatayat NU. Jakarta:

[3] Arnez, Monika. 2010. "Empowering women through Islam: Fatayat NU between tradition and change." Journal of Islamic Studies. 
[4] Budiharto, Widodo, dan Meiliana Meiliana. 2018. "Prediction and analysis of Indonesia Presidential election from Twitter using sentiment analysis." Journal of Big Data 65(2018).

[5] Daoust, Jean François, dan Katherine V.R. Sullivan. 2017. "Campaign-specific information and media effects." Canadian Journal of Communication.

[6] Gumilang, A. 2018. "Hari ini Dilantik sebagai Bupati dan Wakil Bupati Tegal, Yuk Mengenal Lebih Dekat Sosok Umi-Ardie!,."

[7] Haboddin, Muhtar. 2012. Menguatnya Politik Identitas Di Ranah Lokal. Yogyakarta : Jurnal Studi Pemerintahan, 2012. Vol. 03.

[8] Hamidah, Hamidah. 2016. "Indonesian Islamic Movement Of Women: A Study Of Fatayat Muslimat Nu (1938-2013).” MIQOT: Jurnal Ilmu-ilmu Keislaman.

[9] Herrnson, Paul S., J. Celeste Lay, dan Atiya Kai Stokes. 2003a. "Women running 'as women': Candidate gender, campaign issues, and voter-targeting strategies." Journal of Politics.

[10] 2003b. "Women running 'as women': Candidate gender, campaign issues, and voter-targeting strategies.” Journal of Politics 65(1): 244-55.

[11] Indo Institute Survey and Strategy (ISS). 2018. Survey Politik Identitas Pilkada 2018. Jakarta : Indo Institute Survey and Strategy (ISS), 2018.

[12] internetworldstats. 2021. Www.internetworldstats.com. https://www.internetworldstats.com/stats.htm. [Online] WORLD INTERNET USAGE AND POPULATION STATISTICS, 2021. [Cited: 08 17, 2021.]

[13] Iravani, Mohammad Reza. 2010. "Role of Social Capital on Development." Journal of Alternative Perspectives in the Social Sciences.

[14] Irawanto, Budi. 2018. "Political Machinery or Women's Network?: The Case of East Java's 2018 Gubernatorial Election."

[15] ISEAS. 2019. "Social Media and Indonesia's 2019 Elections." www.iseas.edu.sg/medias/event-highlights/item/9277-social-media-and-indonesias2019-elections.

[16] Kuyucu, Mihalis (Michael). 2018. "Usage of Social Media by Politicians During Election Campaign: Comparative Analysis About Presidential Elections in Turkey on June 24th, 2018". Proceedings of International Conference on Multidisciplinary Research Advancement in Social Sciences MRAS-2018.” In Usage of Social Media by Politicians During Election Campaign: Comparative Analysis About Presidential Elections in Turkey, Athens, Greece: Multidisciplinary Research Advancement in Social Sciences MRAS-2018, 1-29.

[17] Lestari, Yeni Sri. 2018. Politik Identitas Di Indonesia: Antara Nasionalisme Dan Agama . Malang : Journal of Politics and Policy , 2018. Volume 1, Number 1, Desember 2018.

[18] Lin, Hsin Chen. 2017. "How political candidates' use of facebook relates to the election outcomes." International Journal of Market Research.

[19] Maarif, Ahmad Syafii. 2010. "Politik Identitas dan Masa Depan Pluralisme Indonesia." Politik Identitas dan Masa Depan Pluralisme Indonesia.

[20] Maarif, A. S. (2012). Politik Identitas dan Masa Depan Pluralisme Indonesia. In Politik Identitas dan Masa Depan Pluralisme Kita (p. 3).

[21] Nastiti, Aulia, dan Sari Ratri. 2018. "Emotive Politics: Islamic Organizations and Religious Mobilization in Indonesia." Contemporary Southeast Asia; ISEAS - Yusof Ishak Institute 40(02): 196-221.

[22] Prihatini, Eli S. 2018. "Measuring Women Chances of Winning in Indonesia's 
Regional Elections,.”

[23] Robert D Putnam. 1995. "Tuning In, Tuning Out: The Strange Disappearance of Social Capital in America Theories and Measures of Social Capital." Political Science \& Politics.

[24] Stier, Sebastian, Arnim Bleier, Haiko Lietz, dan Markus Strohmaier. 2018. "Election Campaigning on Social Media: Politicians, Audiences, and the Mediation of Political Communication on Facebook and Twitter." Political Communication.

[25] Torik, A. 2018. "Muslimat NU Mendominasi Pilkada Jatim 2018, Pengamat: Solidnya Mengalahkan Kekuatan Partai."

[26] Triantoro, Dony Arung. 2019. Praktik Politik Identitas dalam Akun Media Sosial Anies-Sandi. Yogyakarta : Universitas Islam Negeri (UIN) Sunan Kalijaga , 2019

[27] Vonderschmitt, Kaitlin. 2012. The Growing Use of Social Media in Political Campaigns: How to use Facebook, Twitter and YouTube to Create an Effective Social Media Campaign. Kentucky

http://digitalcommons.wku.edu/stu_hon_theseshttp://digitalcommons.wku.edu/stu_hon theses/360 (Maret 8, 2020).

[28] Yangmin Kim* and Albert A. Cannella, J. (2008). Toward a Social Capital Theory ofDirector SelectionNo Title. CORPORATE GOVERNANCE, 16. 